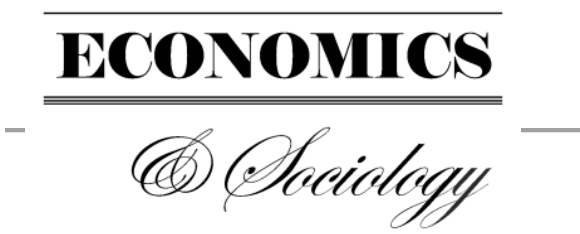

\title{
MONEY ILLUSIONS: POST- REDENOMINATION SHOPPING BEHAVIOR
}

\author{
Bulan Prabawani, \\ Diponegoro University, \\ Semarang, Indonesia, \\ E-mail:bulan@live.undip.ac.id
}

Received: April, 2018

1st Revision: July, 2018

Accepted: August, 2018

DOI: $10.14254 / 2071-$

789X.2018/11-3/10
Prabawani, B. (2018). Money Illusions: Post Redenomination Shopping Behavior. Economics and Sociology, 11(3), 161-169. doi:10.14254/2071-789X.2018/11-3/10

\begin{abstract}
Money illusions potentially occur in a post-redenominating country. This is triggered by the public tendency to merely pay attention to the nominal value listed on the currency rather than the real value. Money illusion often occurs in Indonesian society and encourages hyperinflation, as one indicator of redenomination failure. Therefore, this research explores the potential of money illusion in Indonesia with Semarang, Kudus, and Banjarnegara as the research locations. These three locations represent Indonesian urban, coastal and inland areas. The data collection was conducted with a survey of 600 respondents. The data were analyzed with Cramer's V-test in order to know the potential difference of money illusion among people with different geographic, demographic, and psychographic characteristics. The results show there is a potential for money illusion in terms of educational expenses by educational level; social spending by region; electricity expenses by occupation; water expenses by occupation; entertainment spending by age and sex; and medical expenses by occupation. Hence, the government should provide additional programs to increase the people's understanding of the redenomination agenda and provide strong policies to maintain economic stability.
\end{abstract}

Keywords: money illusion, spending behavior, redenomination, Indonesia, survey, Cramer's V-test.

\author{
JEL Classification: D12, \\ D14, D15
}

\section{Introduction}

Money illusion is the tendency of a person to pay more attention to the nominal value of a currency rather than its real value, i.e. purchasing power (Mees \& Frances, 2014). In the context of redenomination in Indonesia, money illusion has high probability of occurence, especially if it is not accompanied by appropriate socialization (Prabawani, 2017) that causes limited economic cognition (Seiler, 2014). Money illusion is related not only to redenomination, but also to many other financial phenomena. The research of Ma, Wang, Cheng, \& Hu (2018) shows that money illusion, an irrational decision, can cause nominal shock risk and affect equilibrium quantities, depending on investors' beliefs in some aspects of the economy. Yamamori, Iwata, \& Ogawa (2018) added that people tend not to perform optimum consumption due to nominal values and fluctuating prices. Optimal consumption is achieved depending on the real conditions, not on the nominal value. 
In Indonesia, the phenomenon of money illusion requires serious attention from the Government because its presence at the times of post redenomination threatens with the occurrence of hyperinflation (Mosley, 2005) as it happened in Ghana and Zimbabwe (Dzokoto, Mensah, Twum-Asante, \& Opare-Henaku, 2010). The inflation rate in Ghana before redenomination was $10.7 \%$ and increased to $20 \%$ after redenomination (Dzokoto, Mensah, et al., 2010). Dzokoto et al. (2010)indicated that hyperinflation was due to the increasing prices for goods and services, as well as changes in spending behavior (economic factors) and social activities (social factors).

Seiler (2014) states the potential of money illusion can be reduced by conducting an adequate economic analysis. A strong policy is needed to overcome the housing bubble, especially when compared to other monetary instruments such as low interest rate and even inflation reduction (Bernanke, 2010; Brunnermeier \& Julliard, 2007). In this case, households' and individual behavior becomes an important factor in estimating the impact of redenomination. Households are indeed the smallest economic entities in a community, however, their impact on the macroeconomy is significant.

Improper perceptions of the economy, growth, and risk of assets are able to change people's consumption patterns (Miao \& Xie, 2013). A study by Purwana, Warokka, and Buchdadi (2012) on the lower middle class in Jakarta found that family habits in managing monthly fees play an important role in increasing the influence of money illusion, especially on urban communities. Money illusion plays a big role with the potential to disrupt the economy (Bernanke, 2010; Brunnermeier \& Julliard, 2007).

Seiler (2014) shows that money illusion can be reduced if the individual thinks economically in deciding to buy a good or a service. This study explores the potential of money illusion in the behavior of household expenditure based on various individual characteristics in terms of geographic, demographic, and psychographic aspects. Hence, this research predicts that the potential for money illusion exists in the socioeconomic conditions of Indonesian people with different backgrounds. This study has also made an attempt to predict the socioeconomic groups that would be mostly likely to experience money illusion.

\section{Literature review}

There are a number of previous studies that explore money illusions in different countries using various theories and approaches. In China and the US, Mees \& Franses (2014) used Non-parametric Pearson Chi-square tests with two-sided p-values to examine the difference in money illusions between students and Alibaba workers. As a result, there is no significant difference between money illusions in either country. This study also found that the people's consumption patterns that encourage money illusion are not only economic considerations, but also happiness, morality, and job satisfaction. Using the proxy of job satisfaction, the research of Boes (2007) in Germany found that, on the contrary, money illusion can be avoided by increasing proportional income from year to year, thus affecting individual satisfaction. The interesting thing is that people in the US are more likely to experience money illusion because they are more prosperous, so they experience more illusions of happiness (Akerlof, G.A. and R.J. Shiller, 2009 in Mees \& Frances, 2014). There is also an argument that money illusion can be driven by animal spirit and moral hazards in which humans can act irrationally and inefficiently (Marinescu, 2012)

Dissimilar to the study by Mees \& Frances (2014) that only involves young people, a research by Seiler (2014) tests money illusion on the household sector. The study involved 1865 experiment questionnaires that were distributed throughout the US. The data were analyzed using Levine statistics to make appropriate assumptions about the homogeneity of variations before using t-tests for independent samples. The study found that money illusion 
affects the potential desire to buy a house even when the price is beyond the buyer's financial ability; this is driven by the economic considerations in which property prices experience an increase, thus becoming an inevitable need.

Concerning the stock market, Svedsäter, Gamble, and Gärling (2007) conducted three experiments. The first experiment discussed the expectations of changes in share prices, the second experiment discussed the representation of share value in euros and Swedish crowns, and the third experiment discussed the effects on trading splits and reverse splits. The first and second experiments were tested using regression analysis, while the third experiment was tested with the analysis of variance (ANOVA) and t-tests. Experiments 1 and 2 indicate that money illusion affects stock price estimates; the market becomes more dynamic after the stock split, where the value of the stock did not change, but the nominal value decreased. The results of experiment 3 were not in accordance with the impact of money illusion where traders experienced problems in adjusting money illusion or compression effect.

In Indonesia, money illusion cannot be avoided. A survey research in Jakarta, the capital city, found that among middle-lower society in urban areas with high education and an understanding of the concept of time value of money (TVM) even experienced money illusion. High spending especially happened in secondary need consumption (Purwana et al., 2012). In contrast, money illusion in Ghana is avoidable when there is adequate public education (Dzokoto, Young, \& Mensah, 2010), similar to the case in Indonesia in the context of redenomination (Prabawani, Musfirowati, \& Riandhita, 2018).

In a redenomination context, people would tend to be more careful in spending larger denominations rather than smaller ones. Psychologically, people have higher spending control with larger denominations (Raghubir \& Srivastava, 2009). Thus, redenomination that makes the nominal value smaller, irrespective of the real value, has the potential to encourage money illusion. In Indonesia and Ghana, redenomination can strengthen the exchange rate and reveal real economic conditions, but it also has the potential to stimulate rush and hyperinflation if it is not accompanied by adequate socialization (Dzokoto, Young, et al., 2010; Prabawani, 2017; Prabawani et al., 2018). The money illusion phenomenon would weaken the theory that humans economically behave rationally, even though such behavior may only be temporary. Individuals will act rationally after understanding the economic context. (Fehr \& Tyran, 2007)

Previous research related to money illusion was done in the US, China (Mees \& Frances, 2014; Seiler, 2014), Ghana (Dzokoto, Mensah, et al., 2010), Germany (Boes et al., 2007), and Indonesia (Prabawani, 2017; Prabawani et al., 2018). Research focused on various kinds of consumers; some involved only young people (Seiler, 2014) while others focused on middle lower urban communities (Purwana et al., 2012), students and workers (Boes et al., 2007; Mees \& Frances, 2014), and entrepreneurs (Prabawani, 2017; Prabawani \& Prihatini, 2014). In addition, one previous study focused on a normal economic condition; specifically considering inflation and mortgage costs (Brunnermeier \& Julliard, 2007). Studies focusing on redenomination have become a discourse in Indonesia in recent years and involve people from a variety of geographic and demographic backgrounds.

This study predicts that money illusion does not only occur in developing countries with low socioeconomic status, but also in developed countries. Money illusion is driven by rational and irrational factors. The rational factors that encourage money illusion include products of basic needs such as food and shelter, whereas irrational factors are happiness and morality, and job satisfaction. Product types that have the potential to irrationally promote money illusion are products that are not among the basic needs, specifically secondary and tertiary products including stock prices. Conversely, products that incur rational money illusion are products of basic needs, such as housing. 


\section{Methodological approach}

This is a survey-based descriptive research which was conducted in Semarang, Kudus, and Banjarnegara, Central Java. These three areas are representative of Indonesian society in urban, rural, coastal, and inland areas. Semarang is the capital city of Central Java with the characteristics of urban communities. This city is an industrial city in the coastal area. Kudus is also in the coastal area, but this region is a representation of rural communities, even though with a geographical distance that is relatively close to the capital city. Thus, people in Kudus work both in the industrial and agricultural sectors. Banjarnegara is an inland and rural area. This region is far from the capital city with the majority of people working in the agricultural sector.

The total number of respondents was 600 people; 200 each from Semarang, Kudus, and Banjarnegara. Not all of the respondents responded and gave answers to the prediction of changes in consumption patterns of post redenomination. The majority of respondents who did not give an answer stated that they did not know or could not predict the possibility of future prices. Therefore, respondents who did not provide answers were excluded from the analysis. Here is the valid number of respondents involved in each consumption pattern analysis:

Table 1 Respondent numbers

\begin{tabular}{lcccccccc}
\hline Respondent & Food & Education & Social & Clothing & Electricity & Water & Leisure & Medicine \\
\hline Number & 590 & 311 & 421 & 333 & 423 & 231 & 332 & 235 \\
\hline $\begin{array}{l}\text { Response } \\
\text { rate }\end{array}$ & $98 \%$ & $52 \%$ & $70 \%$ & $56 \%$ & $71 \%$ & $39 \%$ & $55 \%$ & $39 \%$ \\
\hline
\end{tabular}

Source: own compilation

The survey was conducted by convenience sampling. The respondents were the decision makers for household consumption. Thus, the respondent was the father or mother, or the adult child. In total, respondents represent a variety of geographic, demographic, and socio-economic backgrounds as follows:

Tabel 2 The number and percentage of respondent characteristics

\begin{tabular}{lcrr}
\hline Characteristics & Sex & Number & Percentage \\
\hline & & 319 & \\
\hline a. Male & Age & 281 & 53,2 \\
\hline b. Female & & 46 & \\
\hline & & 175 & 7,7 \\
\hline a. $<21$ year & 166 & 29,2 \\
\hline b. 21 - 30 year & & 106 & 27,7 \\
\hline c. $31-40$ year & 88 & 17,7 \\
\hline d. $41-50$ year & Family status & 19 & 14,7 \\
\hline e. $51-60$ year & & & 3,2 \\
\hline f. $>60$ year & & 165 & 27,5 \\
\hline & & 247 & 41,2 \\
\hline Children & & 188 & 31,3 \\
\hline Father & Marital status & & \\
\hline Mother & & 433 & 72,2 \\
\hline
\end{tabular}


RECENT ISSUES IN SOCIOLOGICAL RESEARCH

\begin{tabular}{|c|c|c|}
\hline Not married & 167 & 27,8 \\
\hline \multicolumn{3}{|c|}{ Expenditure/month } \\
\hline a. $\leq \mathrm{Rp} 2,5$ million & 336 & 56,0 \\
\hline b. >Rp2.5 - Rp5 million & 198 & 33,0 \\
\hline c. >Rp5 - Rp7.5 million & 33 & 5,5 \\
\hline d. >Rp7.5 - Rp10 million & 16 & 2,7 \\
\hline e. $>$ Rp10 million & 17 & 2,8 \\
\hline \multicolumn{3}{|c|}{ Dependents } \\
\hline a. 0 - 3 people & 547 & 91,2 \\
\hline b. 4 - 6 people & 51 & 8,5 \\
\hline c. 7 - 9 people & 2 & 0,3 \\
\hline \multicolumn{3}{|c|}{ Education } \\
\hline a. No education/Elementary school & 43 & 7,2 \\
\hline b. Primary school & 81 & 13,5 \\
\hline c. Senior high school & 280 & 46,7 \\
\hline d. Bachelor/S1 & 177 & 29,5 \\
\hline e. Postgraduate S2/S3 & 19 & 3,2 \\
\hline
\end{tabular}

Source: own compilation

The response rate for consumption of pre and post redenomination was high for food, social, and electricity spendings, but low for education, clothing, water, leisure, and medicine consumptions. The low response rate was because people found it difficult to predict post redenomination consumption. Moreover, clothing, water, leisure, and medicine are not the main needs of the community.

The data was analyzed using Cramer's V-test (Pallant, 2007) in order to determine the potential difference of money illusion for people of different geographic and demographic characteristics. In addition, magnitude effect size was used to measure the influence of respondents' characteristics to money illusion. The geographic character of each respondent is indicated by the domicile indicator. The demographic characteristics of the respondents include age, gender, family position, education, job, spending level, marital status, and also number of dependents.

\section{Conducting research and the results}

This study explores the potential for money illusion by domicile, age, sex, position in the family, education, position, average expenditure, and the number of family dependents. This is intended to classify the level of public understanding of redenomination in certain segments.

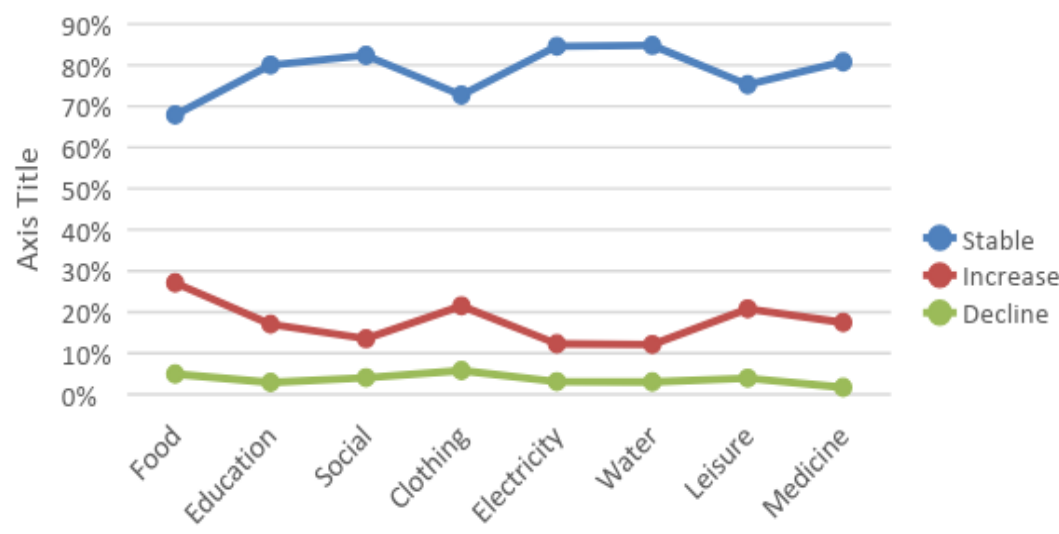

Graph 1 Post-redenomination spending

Source: own compilation 
Graph 1 shows that the majority of people predicted there would be no significant change in food, education, social expenditures, clothing, electricity and water, leisure, and medical spending. In contrast, very few predict that their consumption patterns would decrease or result in less spending. The increase in public spending is predicted to occur primarily in the consumption of food, clothing, and leisure activities, but this has not shown the potential for money illusion post redenomination.

Using Cramer's V-test, this study obtained statistical calculation results as follow:

Table 3 Cramer's V-test significance

\begin{tabular}{|c|c|c|c|c|c|c|c|c|}
\hline Characters & Food & Edu & Social & Clothing & Electricity & Water & Leisure & Medicine \\
\hline a. Domicile & 0,073 & 0,094 & $0,144^{*}$ & 0,113 & 0,033 & 0,083 & 0,066 & 0,119 \\
\hline b. Age & 0,119 & 0,118 & 0,127 & 0,149 & 0,179 & 0,190 & $0,168 *$ & 0,153 \\
\hline c. Gender & 0,038 & 0,021 & 0,055 & 0,062 & 0,105 & 0,125 & $0,153 *$ & 0,084 \\
\hline $\begin{array}{l}\text { d. Family } \\
\text { position }\end{array}$ & 0,062 & 0,057 & 0,092 & 0,058 & 0,084 & 0,136 & 0,109 & 0,097 \\
\hline e. Education & 0,061 & 0,158* & 0,078 & 0,096 & 0,125 & 0,181 & 0,140 & 0,130 \\
\hline f. Job & 0,131 & 0,156 & 0,139 & 0,168 & $0,197 *$ & $0,266^{*}$ & 0,200 & $0,260 *$ \\
\hline g. Spending level & 0,075 & 0,094 & 0,084 & 0,068 & 0,094 & 0,148 & 0,097 & 0,123 \\
\hline h. Marital status & 0,051 & 0,063 & 0,078 & 0,097 & 0,073 & 0,120 & 0,075 & 0,056 \\
\hline $\begin{array}{l}\text { i. Number of } \\
\text { Dependents }\end{array}$ & 0,055 & 0,116 & 0,068 & 0,031 & 0,073 & 0,100 & 0,078 & 0,062 \\
\hline
\end{tabular}

*sig 0,05

Source: own compilation

The Table 3 shows that geographically, there is only the potential for money illusion in social spending. The crosstab data (not shown in this paper) reveal that the people of Semarang and Banjarnegara tend to issue higher social spending than the people of Kudus. However, there are no significant differences in socio-economic characteristics among the three regions. Although the Semarang community is an urban community, it does not make the people in this city more generous or vice versa.

Demographically, there is money illusion in leisure spending at certain ages and genders. People, especially those aged 31-40 years, would spend more money on entertainment. Likewise, the male respondents would tend to spend more money postredenomination. This indicates an irrational decision on economic consumption for tertiary products. Money illusion also potentially occurs in educational expenditure in communities with different levels of education. Those who do not go to school and have only an elementary education have a greater potential for money illusion than those with higher levels of education.

Job type is a control variable that is important in predicting money illusion. People who work as Farmers, Pensioners, and who are employed in Lower Management are more likely to experience money illusion. They would spend more money on electricity, water, and medicine post redenomination. Pensioners even rate that the cost of medication would be higher. The same opinion is delivered by the people who work as Housewives and in Lower Management positions. Using the approaches of Mees \& Frances (2014) and Boes (2007), the existence of spending based on the type of work on the consumption of electricity, water, and medicine, three basic needs, indicate that the society did not experience job satisfaction.

Furthermore, the influence of geographic and demographic control variables on spending behavior was tested statistically by using effect size. The result is as follows: 
Table 4 Effect size

\begin{tabular}{lll}
\hline Characters & $\begin{array}{l}\text { Cons } \\
\text { items }\end{array}$ & $\begin{array}{l}\text { Effect } \\
\text { size }\end{array}$ \\
\hline a. City & Social & Medium \\
\hline b. Age & Leisure & Medium \\
\hline c. Gender & Leisure & Medium \\
\hline e. Education & Education & Medium \\
\hline f. Job & Electricity & Medium \\
\cline { 2 - 3 } & Water & Medium \\
\cline { 2 - 3 } & Medicine & Medium \\
\hline
\end{tabular}

*sig. 0,05

Source: own compilation

The table 4 shows that all the geographic and demographic characters have a considerable influence on money illusion, on social consumption, leisure, education, electricity and water, and also medicine expenditures.

This research shows that money illusion has the potential to occur in Indonesia after a redenomination policy and is driven by the factors of residential location, age, gender, education, and type of work. These variables affect spending on consumption such as social donations, entertainment, education, electricity and water, and medication. What is predicted to happen in Indonesia is relatively similar to that in Ghana, where money illusion is driven by the perception that the price of goods and services seemed cheaper after the redenomination (Dzokoto et al., 2010). As a result, hyperinflation occurs. However, monetary policies can be made to correct deviations in decisions to consume or to save of those people who experience money illusions (Xie \& Miao, 2007).

Residential location affects social expenditure because each region in Indonesia has a unique local culture and wisdom. Both of these affect the behavior of the community in the amount of social donations contributed towards marriage, circumcision, death, and birth. Age affects entertainment activity as each age group has different entertainment preferences. People from 31-40 years of age spend more money on entertainment. Similarly, in the leisure spending, males tend to spend more money post redenomination.

The urban people who are assumed to have adequate educations cannot be totally free of illusions in making transactions (Purwana et al., 2012). However, there is a greater potential for money illusion in low-educated communities; this is because of their lack of understanding of redenomination. For that, a proper approach for the special characteristics of the segment becomes crucial (Prabawani, 2018).

Similar to the facts of money illusion in the lower education class, money illusion is also more likely in people who do not work or who work as blue collar workers. These types of jobs include Housewives, Retirees, Farmers, and Lower Management. These jobs are quite identical to the lack of information regarding economy or national issues. This is a different case from the research in the US and Germany, in which job satisfaction encourages people to be more irrational due to a proxy of happiness (Boes et al., 2007; Mees \& Frances, 2014).

Money illusion of post redenomination is the result of the unpreparedness and poor planning. Hence, Indonesia needs to find some lessons learned from countries that have successfully implemented redenomination and conduct proper education for the community (Mees \& Frances, 2014). 


\section{Conclusion}

This study proves that the social economic diversity of Indonesian society affects their understanding of redenomination. In general, people understand that redenomination would not change the value of money, so it does not change the pattern of public consumption. However, money illusion has the potential to occur in some characteristics of society, especially based on domicile, age, gender, type of education, and certain occupations. The consumption pattern is mainly affected for social, leisure, education, electricty, clothing, and water, as well as medicine spending. Therefore, both the central and the local governments need to take different approaches to certain groups of people. This research has also proved that money illusion with an irrational decision occurs in secondary and tertiary consumptions. Irrational decisions happened due to the proxy of happines. The money illusion with a rational decision occurs in basic needs caused by people's low level of job satisfaction. Thus, money illusion can be avoided by annually increasing a proportional income that will affect individual satisfaction. However, this is a perceptual study so that experimental research would be more valid in predicting money illusion. In addition, the product types need to specifically represent primary, secondary, and tertiary products.

\section{Acknowledgement}

This research has been funded by the Indonesian Ministry of Research, Technology, and Higher Education under competitive scheme no. 344-11/UN7.5.1/PP/2017 and no. 10189/UN7.P4.3/PP/2018.

\section{References}

Bernanke, B. S. (2010). Monetary Policy and the Housing Bubble. Journal of Real Estate Finance and Economics, 46(3), 437-451. https://doi.org/10.1007/s11146-011-9329-9

Boes, S., Lipp, M., \& Winkelmann, R. (2007). Money illusion under test. Economics Letters, 94(1), 332-337. https://doi.org/10.1016/j.econlet.2006.06.043

Brunnermeier, M. K., \& Julliard, C. (2007). Money Illusion and Housing Frenzies. The Review of Financial Studies, 21(1), 1-47.

Dzokoto, V. A. A., Mensah, E. C., Twum-Asante, M., \& Opare-Henaku, A. (2010). Deceiving Our Minds: A Qualitative Exploration of the Money Illusion in Postredenomination Ghana. Journal of Consumer Policy, 33(4), 339-353. https://doi.org/10.1007/s10603-010-9144-3

Dzokoto, V. A. A., Young, J., \& Mensah, C. E. (2010). A tale of two Cedis: Making sense of a new currency in Ghana. Journal of Economic Psychology, 31(4), 520-526. https://doi.org/10.1016/j.joep.2010.03.014

Fehr, E., \& Tyran, J. (2007). Money illusion and coordination failure. Games and Economic Behavior, 58(1), 246-268. https://doi.org/10.1016/j.geb.2006.04.005

Ma, C., Wang, H., Cheng, F., \& Hu, D. (2018). How money illusions and heterogeneous beliefs affect asset prices. North American Journal of Economics and Finance, 44(December 2017), 167-192. https://doi.org/10.1016/j.najef.2018.01.003

Marinescu, C. (2012). The limit between the rational and irrational behaviour in the economic science. Theoretical and Applied Economics, XIX(6), 143-156. Retrieved from http://store.ectap.ro/articole/742.pdf

Mees, H., \& Frances, P. H. (2014). Are individuals in China prone to money illusion?. Journal of Behavioral and Experimental Economics, 51(1), 38-46. https://doi.org/10.1016/j.socec.2014.03.003 
Miao, J., \& Xie, D. (2013). Economic growth under money illusion. Journal of Economic Dynamics and Control, 37(1), 84-103. https://doi.org/10.1016/j.jedc.2012.06.012

Mosley, L. (2005). Dropping Zeros, Gaining Credibility? Currency Redenomination in Developing Nations. In Annual Meeting of the American Political Science Association (pp. 1-26). https://doi.org/10.1017/CBO9781107415324.004

Pallant, J. (2007). SPSS survival manual : a step by step guide to data analysis using SPSS for Windows (version 10).

Prabawani, B. (2017). Potential Impacts of Redenomination: A Business Perspective. International Journal of Business and Society, 18(2008), 295-308.

Prabawani, B., Musfirowati, I. H., \& Riandhita, E. W. (2018). Socialization : An important factor of redenomination success in Indonesia. Business and Economic Horizons, 14(3), 700-712.

Prabawani, B., \& Prihatini, A. E. (2014). Indonesian Businesses: Coping with Redenomination Policy. Australian Journal of Basic and Applied Sciences, 8(1), 245251.

Purwana, D., Warokka, A., \& Buchdadi, A. (2012). Money Illusion and the Middle-Lower Metropolis: Managing the Financial Phenomenon. The Journal of Southeast Asian Research, 1(1), 1-11. https://doi.org/10.5171/2012.633412

Raghubir, P., \& Srivastava, J. (2009). The Denomination Effect. Journal of Consumer Research, 36(4), 701-713. https://doi.org/10.1086/599222

Seiler, M. J. (2014). Understanding the prevalence and implications of homeowner money illusion. Journal of Behavioral and Experimental Finance, 1(1), 74-84. https://doi.org/10.1016/j.jbef.2014.02.001

Svedsäter, H., Gamble, A., \& Gärling, T. (2007). Money illusion in intuitive financial judgments: Influences of nominal representation of share prices. Journal of SocioEconomics, 36(5), 698-712. https://doi.org/10.1016/j.socec.2007.01.006

Xie, D., \& Miao, J. (2007). Monetary Policy and Economic Growth Under Money Illusion. SSRN Electronic Journal. https://doi.org/10.2139/ssrn.1021921

Yamamori, T., Iwata, K., \& Ogawa, A. (2018). Does money illusion matter in intertemporal decision making? Journal of Economic Behavior and Organization, 145, 465-473. https://doi.org/10.1016/j.jebo.2017.11.019 